\title{
Sistem Informasi Pelaporan dan Penanganan Kerusakan Fasilitas Kelas Studi Kasus : Universitas Kristen Duta Wacana
}

\author{
Rina Widiana Sari ${ }^{1}$, Wimmie Handiwidjojo ${ }^{2}$, Lussy Ernawati ${ }^{3}$ \\ Program Studi Sistem Informasi, Universitas Kristen Duta Wacana \\ Jl. Dr. Wahidin Sudirohusodo No. 5-25, Yogyakarta \\ ${ }^{1}$ rina.widianaesi.ukdw.ac.id \\ ${ }^{2}$ whanz@staff.ukdw.ac.id \\ ${ }^{3}$ lussyestaff.udkw.ac.id
}

\begin{abstract}
Class facilities are one of the supports in the teaching and learning process including all lecture facilities provided at Duta Wacana Christian University (UKDW). However, sometimes there are still students and lecturers who complain because there are facilities that do not function or have problems when used in class. Previously, UKDW had provided a means for lecturers to report class condition complaints in the form of sheets placed in the lecture presence, but this was less effective because it was still manual and there could be a loss of report paper, thus hampering the process of repairing the complained of facilities. Therefore, it is necessary to create a system that is able to deal with these problems with the Classroom Reporting and Damage Management Information System. Through this system lecturers can make complaints in the form of facility damage reports which will then be stored in a database. in addition, lecturers and administrators (biro 1) can monitor the report processing process through a work process checklist that will be provided by unit, and also unit can visualize facilities that often suffer damage through a dashboard in graphical form. With the construction of this system, it can facilitate lecturers in reporting complaints if there are facilities that are problematic when used during lectures. So that unit responsible for managing the facility can immediately carry out the repair process immediately.
\end{abstract}

Intisari - Fasilitas kelas menjadi salah satu pendukung dalam proses belajar mengajar termasuk segala fasilitas perkuliahan yang disediakan di Universitas Kristen Duta Wacana (UKDW). Namun, terkadang masih ada mahasiswa maupun dosen yang mengeluh karena terdapat fasilitas yang tidak berfungsi atau bermasalah ketika digunakan didalam kelas. UKDW sebelumnya sudah menyediakan sarana bagi dosen untuk melaporkan keluhan kondisi kelas dalam bentuk lembaran yang diletakkan di dalam presensi perkuliahan, namun hal tersebut kurang efektif karena masih bersifat manual dan bisa saja terjadi hilangnya kertas laporan sehingga menghambat proses perbaikan dari fasilitas yang dikeluhkan.

Oleh karena itu, perlu dibuat sebuah sistem yang mampu menangani masalah tersebut dengan Sistem Informasi Pelaporan dan Penanganan Kerusakan Fasilitas Kelas. Melalui sistem ini dosen dapat melakukan keluhan berupa laporan kerusakan fasilitas yang kemudian laporan tersebut akan disimpan kedalam database. selain itu juga dosen dan admin (biro 1) dapat memantau proses pengerjaan laporan melalui checklist proses kerja yang akan diberikan oleh unit, dan juga unit dapat memvisualisasikan fasilitas yang sering mengalami kerusakan melalui dashboard dalam bentuk grafik.

Dengan dibangunnya sistem ini, dapat memfasilitasi dosen dalam melaporkan keluhan apabila terdapat fasilitas yang bermasalah ketika digunakan saat perkuliahan berlangsung. Sehingga unit yang bertanggung jawab dalam mengelola fasilitas dapat segera melakukan proses perbaikan dengan segera.

Kata Kunci- Fasilitas, Sistem, Laporan, Kerusakan, Dashboard

\section{Pendahuluan}

Universitas Kristen Duta Wacana (UKDW) merupakan salah satu universitas swasta yang didalamnya terdapat unitunit yang memiliki tugas dan fungsi berbeda-beda. Terdapat berbagai ruang lingkup yang menjadi fokus kerja setiap unit seperti pengelola bidang perkuliahan, fasilitas kampus, alumni, hingga yang berkaitan dengan pihak luar kampus.

Salah satu faktor yang masih menjadi keluhan di UKDW yaitu mengenai fasilitas kelas yang bermasalah seperti AC, proyektor, PC, presensi, perabotan, hingga fasilitas lainnya yang dimanfaatkan saat kelas berlangsung. Dosen-dosen atau mahasiswa yang menggunakan kelas saat perkuliahan sering menemui fasilitas yang rusak (tidak dapat digunakan), fasilitas yang sering bermasalah tersebut termasuk fasilitas yang sudah lama tidak dilakukan perbaikan. Hal tersebut juga menjadi kendala untuk segera dilakukan perbaikan apabila tidak ada pihak yang segera melapor kepada unit yang berwewenang pada pengelolaan fasilitas kelas. Unit tersebut antara lain KRT, PUSPINdiKA, PPLK. Sebenarnya sudah ada fasilitas seperti formulir yang disertakan didalam presensi mahasiswa yang digunakan untuk melaporkan bila terjadi kerusakan, namun form tersebut kurang efektif karena masih bersifat manual dan bila memakai kertas dapat mengakibatkan hilangnya kertas laporan, sobek, dan tidak ringkas sehingga keluhan dari dosen tersebut tidak terdokumentasi dan tersalurkan ke unit-unit terkait yang bertanggungjawab dalam memelihara fasilitas kelas.

Berdasarkan permasalahan tersebut, penulis mencoba membuat sistem informasi berbasis web yang dapat digunakan oleh setiap unit dan dosen, agar setiap keluhan bisa lebih terpusat dan terdokumentasi dengan baik sehingga tujuan permasalahan fasilitas kelas bisa segera dilakukan tindakan dan tidak menghambat proses kegiatan akademik. 


\section{II.LANDASAN TEORI}

\section{a. Fasilitas Kelas}

Dalam dunia pendidikan sekolah maupun perguruan tinggi, bukan hanya dari materi pelajaran dan pengajar yang sangat berperan penting dalam pendidikan namun menurut jurnal [1] menunjukan bahwa fasilitas belajar dan motivasi belajar juga akan sangat berperan di dalam keberhasilan proses pembelajaran. Pemenuhan dan pengelolaan fasilitas belajar berupa sarana dan prasarana perlu mendapat perhatian yang lebih, sehingga tujuan pembelajaran dapat tercapai dengan baik. Motivasi siswa juga menjadi hal yang tidak boleh diabaikan dalam belajar, karena dengan adanya motivasi siswa untuk belajar, proses pembelajaran akan berlangsung dengan baik.

Permasalahan terkait tentang fasilitas pembelajaran sama rumitnya dengan permasalahan pendidikan itu sendiri, karena fasilitas pembelajaran meliputi semua sarana dan prasarana yang diperlukan dalam proses belajar mengajar baik yang bergerak maupun tidak bergerak agar pencapaian tujuan pembelajaran dapat berjalan lancar, teratur, efektif dan efisien sehingga seorang dosen dapat melaksanakan kegiatan pembelajran dengan kinerja yang baik dan siswa dapat memperoleh hasil pembelajaran yang maksimal [2].

\section{b. Pelaporan dan Penanganan}

Pelaporan merupakan bentuk timbal balik dari konsumen yang berisi informasi yang unik dan berharga, sehingga organisasi dapat memperhatikan peningkatan kualitas dan manajemen resiko. Dengan begitu maka pengaduan atau pelaporan merupakan elemen penting bagi pengembangan suatu organisasi. Karena dengan adanya pengaduan, organisasi dapat mengetahui apa yang menjadi kelemahannya dalam menyelenggarakan pelayanan kepada masyarakat. Dengan mengetahui kelemahan tersebut, maka organisasi terdorong untuk meningkatkan kualitas. Sedangkan penanganan dari pelaporan adalah masalah utama yang harus diperhatikan oleh pengambil kebijakan. Penanganan laporan merupakan salah satu komponen penting dalam rangka peningkatan kepuasan pengguna layanan dan dukungan pengguna layanan terhadap penyedia layanan tersebut [3].

\section{c. Sistem Informasi}

Sistem adalah suatu kumpulan komponen yang membentuk suatu jaringan kerja yang saling terhubung untuk melakukan suatu kegiatan guna mencapai sasaran tertentu [4].

Pengertian informasi merupakan data yang diolah menjadi bentuk yang lebih berguna dan lebih berarti bagi penerimanya. Sumber informasi adalah data. Data kenyataannya yang menggambarkan suatu kejadian-kejadian dan kesatuan nyata. Kejadian-kejadian (event) adalah kejadian yang terjadi pada saat tertentu [5].

Sistem informasi merupakan sistem di dalam suatu organisasi yang berfungsi mengolah transaksi harian, mendukung operasi, serta menyediakan informasi yang diperlukan bagi pihak yang berkepentingan. Selain itu juga sistem informasi menjadi seperangkat komponen saling berhubungan dan berintegrasi yang berfungsi memproses, mendistribusikan, serta menyimpan informasi guna mendukung keputusan dan pengawasan di dalam suatu organisasi [6].

\section{d. Web Database}

Database atau basis data adalah kumpulan data yang disimpan secara sistematis di dalam komputer dan dapat diolah atau dimanipulasi menggunakan perangkat lunak (program aplikasi) untuk menghasilkan informasi. Pendefinisian basis data meliputi spesifikasi berupa tipe data, struktur, dan juga batasan-batasan data yang akan disimpan. Basis data merupakan aspek yang sangat penting dalam sistem informasi dimana basis data merupakan gudang penyimpanan data yang akan diolah lebih lanjut. Basis data menjadi penting karena dapat menghidari duplikasi data, hubungan antar data yang tidak jelas, organisasi data, dan juga update yang rumit [7].

Alat atau sarana temu kembali yang berbasis komputer seperti database memiliki kelebihan dalam proses penemuan kembali arsip yang dibutuhkan dalam waktu yang cepat. Kelebihan dari database yaitu seorang arsiparis dapat dengan cepat mengetahui dimana letak penyusunan arsip yang dicari dengan melihat database yang telah dirancang dengan input data berdasarkan letak atau tempat penyimpanannya. Database yang digunakan dalam pengelolaan arsip dapat dibuat dengan memanfaatkan web sebagai sarana pendukung perancangan sebuah database [8].

\section{e. Web Desain}

Website adalah kumpulan dari halaman-halaman yang berisi informasi melalui jalur internet yang diakses melalui berbagai perangkat di seluruh dunia. Halaman tersebut merupakan komponen-komponen yang terdiri dari beberapa unsur, yakni teks, gambar, audio, video, dan animasi dari berbagai bentuk sehingga menjadi media informasi yang menarik untuk dikunjungi.. Salah satu bentuk sarana pemasaran produk perusahaan adalah penyebaran informasi menggunakan website. desain website yang menarik menjadi sangat penting agar tujuan perusahaan mudah dipelajari dan dapat diterima oleh calon konsumen khususnya dalam merancang tampilan (interface). Untuk memenuhi kebutuhan pengguna (user), desain website harus memenuhi prinsipprinsip perancangan layout dan composition dalam membangun tampilan (interface) website [9].

Dalam buku yang berjudul Step by Step WEB Design; Theory and Practices, ada beberapa kriteria yang dapat diperhatikan agar website yang diciptakan dapat dikatakan sebagai website yang baik [10]. Kriteria-kriteria tersebut antara lain :

\section{Kegunaan (usability)}

Usability dapat melibatkan pertanyaan mengenai "dapatkah user menemukan cara untuk menggunakan untuk menggunakan situs web tersebut dengan efektif “ atau sebagai pengalaman pengguna dalam berinteraksi dengan aplikasi atau situs web sampai pengguna dapat mengoperasikannya dengan mudah dan cepat.

2. Sistem navigasi (struktur)

Struktur membantu pengunjung untuk menemukan jalan yang mudah ketika menjelajahi situs web. Navigasi ini dapat ditampilkan dalam berbagai media yaitu teks, gambar, ataupun animasi.

3. Desain visual (graphic desain)

Kepuasan visual seorang user secara subyektif melibatkan bagaimana desainer visual situs web tersebut membawa mata user menikmati dan menjelajahi situs web dengan melalui layout, warna, bentuk, dan tipografi. 
4. Kompatibilitas (compatibility)

Situs web harus kompatibel dengan berbagai perangkat tampilannya harus memberikan alternatif bagi browser yang tidak dapat melihat situsnya.

5. Lama respon (loading time)

Dalam penerapan lama respon akan sangat berguna bagi pengguna karena semakin cepat respon browser yang digunakan maka akan semakin cepat juga pengguna mendapatkan informasi. Namun apabila saat membuka halaman web namun responnya lama hingga beberapa detik kemungkinan pengguna kemungkinan akan menutup browser tersebut.

6. Konten (contens)

Konten yang baik akan menarik, relevan, dan pantas untuk target pengguna situs web tersebut. Gaya penulisan dan bahasa yang dipergunakan harus sesuai dengan web dan target pengguna. Hindari kesalahan dalam penulisan, termasuk tata bahasa, dan tanda baca tiap halaman, header dan judulnya.

7. Fungsionalitas (functionality)

Seberapa baik sebuah situs web bekerja dari aspek teknologinya, tetap akan melibatkan programmer dengan script. Misalnya HTML, PHP, ASP, CGI, SSI, dll.

8. Aksesibilitas (accessibility)

Halaman web harus bisa digunakan oleh setiap orang, baik anak-anak, orang tua, dan orang muda termasuk orang cacat. Ada berbagai hambatan yang ditemui dari sisi pengguna untuk bisa menikmati halaman web tersebut. Contohnya untuk halaman fisik, bagaimana memaksimalkan pengguna konten ketika satu atau lebih indera dimatikan atau dikurangi kerjanya, terutama untuk user dengan kekurangan indera penglihatan. Selain itu ada juga hambatan infrastruktur seperti akses internet yang lambat.

9. Interaktivitas (interactivity)

Interaktivitas merupakan apa yang menggunakan pengguna situs web sebagai user experience dengan situs web itu sendiri. Dasar dari interaktivitas adalah hyperlinks (link) dan mekanisme feedback. Gunakan hyperlink untuk membawa pengunjung kesumber berita, topik lebih lanjut, topik terkait, atau lainnya.

\section{f. System Development Life Cycle}

Metode Waterfall adalah suatu proses pengembangan perangkat lunak berurutan, di mana kemajuan dipandang sebagai terus mengalir ke bawah (seperti air terjun) melewati fase-fase perencanaan, pemodelan, implementasi (konstruksi), dan pengujian. Keuntungan dari model waterfall antara lain : Kualitas dari sistem yang dihasilkan akan baik. Ini dikarenakan oleh pelaksanaannya secara bertahap. Sehingga tidak terfokus pada tahapan tertentu. Document pengembangan sistem sangat terorganisir, karena setiap fase harus terselesaikan dengan lengkap sebelum melangkah ke fase berikutnya. Jadi setiap fase atau tahapan akan mempunyai dokumen tertentu. Selain itu model waterfall juga terdapat beberapa kelemahan antara lain : diperlukan majemen yang baik, karena proses pengembangan tidak dapat dilakukan secara berulang sebelum terjadinya suatu produk. Kesalahan kecil akan menjadi masalah besar jika tidak diketahui sejak awal pengembangan. Pelanggan sulit menyatakan kebutuhan secara eksplisit sehingga tidak dapat mengakomodasi ketidakpastian pada saat awal pengembangan [7].

Dalam metode waterfall setiap tahap harus diselesaikan terlebih dahulu secara penuh sebelum diteruskan ke tahap berikutnya untuk menghindari terjadinya pengulangan tahapan. Adapun tahapan dari model waterfall antara lain planning, analysis, design, coding, implementation [11].

1. Melakukan survei dan menilai kelayakan projek pengembangan sistem informasi $\rightarrow$ ditentukan ruang lingkup projek bagi semua pemakai sistem informasi dari berbagai tingkat pertanggungjawaban, meneliti masalah yang ada dan berbagai kemungkinan adanya kendala dari segi teknik dan bisnis, menentukan sasaran projek dan menentukan solusi yang mungkin diterapkan. Hasil dari tahap ini adalah laporan studi kelayakan.

2. Mempelajari dan menganilis sistem informasi yang sedang berjalan $\rightarrow$ Pada tahap ini mempelajari sistem informasi yang sedang berjalan sangat berguna untuk mengetahui sebab dan akibat yang ditimbulkan oleh masalah, kesempatan dan pengarahan yang terjadi. Hasil dari tahap ini adalah laporan yang mengungkapkan adanya berbagai permasalahan.

3. Menentukan permintaan pemakai sistem informasi $\rightarrow$ Tahap ini bertujuan untuk mengetahui apa yang diharapkan pemakai sistem dari sistem informasi yang baru. Secara umum keinginan para pemakai sistem informasi dari sistem informasi baru meliputi data (input), pemrosesan (processing), dan hasil (output). Hasilnya adalah laporan permintaan (requierment statement) dari pemakai sistem informasi yang akan dijadikan dasar untuk pembuatan alternatif pemecahan masalah.

4. Memilih solusi atau pemecahan masalah yang paling baik $\rightarrow$ pada tahap ini pemakai sistem akan membantu analis sistem dalam menentukan bagaimana sebaiknya sistem informasi berbasis komputer harus dibuat dan dioperasikan agar sesuai dengan kebutuhan pemakai.

5. Menentukan perangkat keras (hardware) dan perangkat lunak komputer (software) $\rightarrow$ Tahap ini analisis sistem informasi akan mementukan hardware dan software yang akan digunakan.

6. Merancang sistem informasi baru $\rightarrow$ Perancangan sistem informasi baru pada tahap ini umumnya meliputi, output, input, file-file, database, komputer dan bahasa yang digunakan, metode dan prosedur serta pengendalian intern. Nantinya hasil dari tahap ini akan berupa spesifikasi desain yang akan dibangun

7. Membangun sistem informasi baru $\rightarrow$ Tahap pembangunan sistem informasi ini dapat dilakukan oleh programmer dan peranan analis sistem informasi pada tahap ini lebih banyak memberikan pengarahan.

8. Mengkomunikasikan dan mengimplementasikan sistem informasi baru $\rightarrow$ Pada tahap ini analis harus memperkenalkan paket sistem informasi baru tersebut untuk dioperasikan. Pada penerapan sistem informasi baru, analis harus benarbenar berperan sebagai perantara yang dapat membantu pemakai sistem untuk berpindah dari sistem informasi lama ke sistem informasi baru. Jadi intinya tahap ini nantinya akan membuat pelatihan kepada para pengguna sistem informasi ini

9. Memelihara dan melakukan perbaikan / peningkatan sistem informasi baru bila diperlukan $\rightarrow$ Pembuat sistem 
informasi harus tetap terus melakukan pengawasan dan pengembangan, melalui pemeliharaan dan pengembangan sistem informasi.

\section{g. Dashboard}

Dashboard merupakan sebuah model aplikasi sistem informasi yang disediakan bagi para manager untuk menyajikan informasi kualitas kinerja, dari sebuah perusahaan atau lembaga organisasi [12].

Dashboard digunakan sebagai alat untuk menyajikan informasi secara sekilas, solusi bagi kebutuhan informasi organisasi. Dashboard memberikan tampilan antarmuka dengan berbagai bentuk seperti diagram, laporan, indikator visual, mekanisme alert, yang dipadukan dengan informasi yang dinamis dan relevan. Dashboard dikelompokan menjadi 3 jenis yaitu dashboard strategis yang berfungsi untuk mendukung keselarasan organisasi dengan tujuan strategis, dashboard taktis untuk mendukung pengukuran pencapaian hasil dari suatu proyek atau kebijakan, dan dashboard operasional untuk mendukung pengendalian aktivitas bisnis baru [13]. Berikut beberapa manfaat dari dashboard :

1. Kemampuan untuk mengidentifikasi dan mengoreksi kecenderuungan negatif.

2. Kemampuan untuk membuat keputusan yang lebih baik berdasarkan informasi yang di dapat melalui intelejen bisnis.

3. Kemampuan untuk mengukur tingkat efisiensi atau inefisiensi organisasi.

4. Kemampuan untuk melakukan analisis yang lebih baik melalui presentasi visual dari pengukuran kerja.

5. Kemampuan untuk menyelaraskan strategi dengan tujuan organisasi.

6. Meningkatnya produktivitas.

7. Menghemat waktu karena karyawan tidak perlu menyusun laporan berlembar-lembar.

8. Mengurangi kebutuhan membuat dan mengelola laporan statis dalam jumlah besar.

9. Mudah untuk dipelajari sehingga tidak memerlukan pelatihan yang rumit.

\section{ANALISIS DAN PERANCANGAN SISTEM}

\section{a. Tahapan Penelitian}

Sebelum dilakukannya perancangan sistem, terdapat beberapa tahapan atau metode yang digunakan sebagai langkah-langkah untuk pemecahan masalah dalam penelitian ini adalah sebagai berikut :

1. Melakukan wawancara dan pengumpulan data berupa data ruang kelas beserta fasilitas, laporan kondisi kelas lama, dan jadwal dosen yang menggunakan ruang kelas untuk perkuliahan selama satu semester.

2. Melakukan analisis terhadap data yang sudah dikumpulkan untuk kemudian diimplementasikan didalam pembuatan desain database.

3. Membuat desain database dan antarmuka grafis.

4. Pembuatan program dimulai setelah desain database dan antarmuka grafis.

\section{b. Perancangan Sistem}

1. Diagram Use Case

Dalam sistem ini terdapat 3 stakeholder yaitu dosen, unit terkait yang bertanggung jawab dalam pengelolaan fasilitas, dan juga admin. Berikut akan dijelaskan melalui diagram dan deskripsi Use Case.

Diagram Use case merupakan kegiatan atau interaksi yang saling terhubung antara aktor dan juga sistem atau dengan kata lain teknik yang secara umum digunakan untuk mengembangkan suatu perangkat lunak. Dari komponen itu kemudian akan menjelaskan komunikasi antara aktor dengan sistem yang ada agar dapat dipresentasikan dengan urutan yang lebih sederhana. Dari Use Case berikut ini dapat dilihat peran yang dimiliki masing-masing stakeholder didalam sistem. Dimana setiap stakeholder memiliki peran yang berbeda-beda dan setiap peran memiliki satu atau lebih stakeholder. Untuk semua Use case menggambarkan include terhadap login yang artinya semua proses akan dapat dilakukan setelah login dilakukan baik dosen, unit, maupun admin

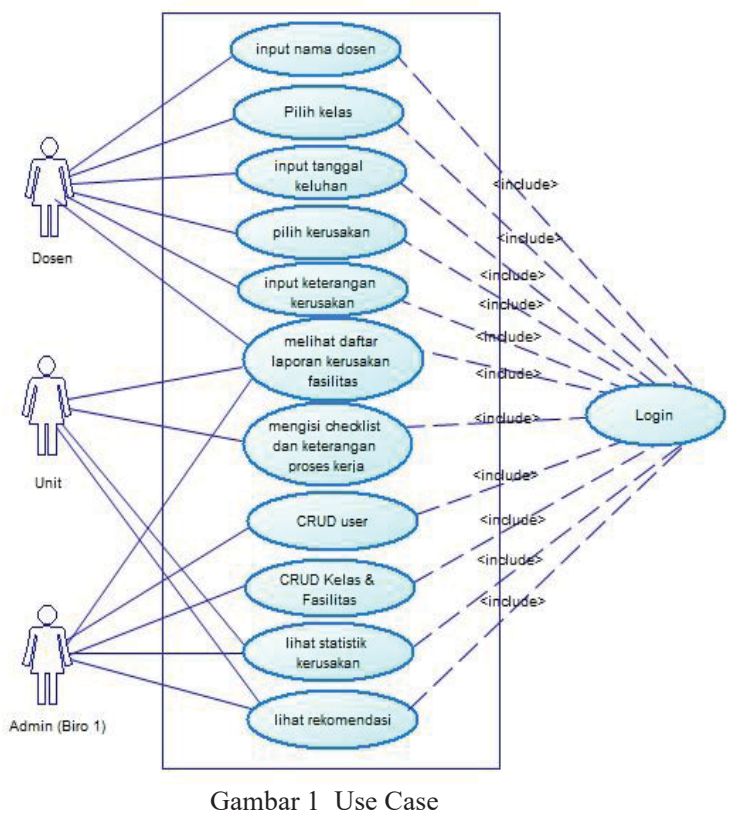

2. Data Flow Diagram (DFD)

Berikut ini adalah Data Flow Diagram (DFD) yang menggambarkan aliran data pada sistem ini. Data Flow Diagram menggambarkan sistem dengan menggunakan simbol-simbol untuk mendeskripsikan aliran data dalam suatu proses yang saling berhubungan. Dengan penggambaran tersebut dapat diketahui dari mana data berasal, bentuk masukan, proses aliran data dan bentuk keluaran data. Penggambaran DFD dimulai dengan penggambaran konteks diagram yang merupakan penggambaran umum dari alur data yang terdapat pada sistem. Dari diagram konteks tersebut selanjutnya akan diuraikan kedalam DFD level 1 dan 2. Pada gambar dibawah ini merupakan rancangan dari diagram konteks atau diagram level 0 dari DFD. Pada level ini, dirancang suatu bagan yang menunjukkan data masukan dan keluaran dari sistem, adapun keluaran dan masukan ini berasal dari entitas yang terkait. Entitas merupakan bagian yang dapat mewakili sesuatu yang nyata eksistensinya dan dapat dibedakan dari sesuatu yang lain. 


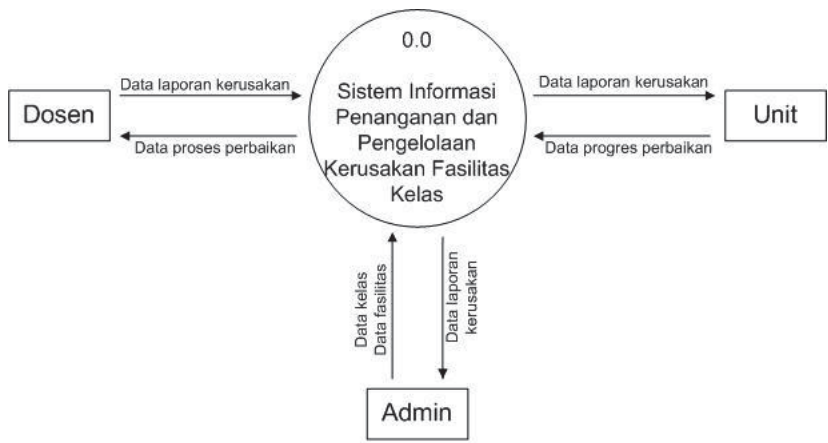

Gambar 2 DFD Level 0 (Diagram Konteks)

Diagram konteks pada gambar 2 menggambarkan relasi dari elemen-elemen yang terhubung dalam Sistem Informasi Pelaporan dan Penanganan Kerusakan Fasilitas Kelas. Pada hal ini terdapat 3 entitas antara lain dosen, unit, admin. Dosen berperan dalam melakukan setup data laporan kerusakan dan dapat memantau data proses perbaikan yang berasal dari sistem. Unit perperan dalam mengelola data progres dari laporan yang diterima. Sedangkan Admin berperan dalam mendaftarkan data kelas dan fasilitas.

\section{Activity Diagram}

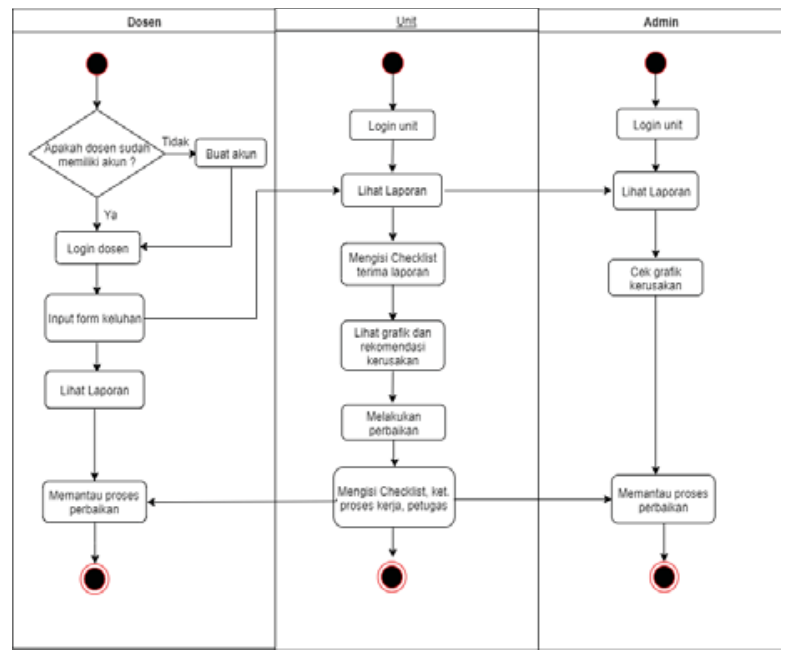

Gambar 3 Activity Diagram Proses Keseluruhan Laporan

Pada bagian ini merupakan diagram activity dari keseluruhan proses laporan kerusakan fasilitas. Dimulai dari dosen yang akan memberikan laporan dengan mengisi form laporan kerusakan fasilitas kelas, kemudian form tersebut akan diterima oleh unit yang bertanggungjawab dalam pengelolaan fasilitas tersebut. Setelah laporan dari dosen tersebut diterima oleh unit, maka unit akan memberikan checklist bahwa laporan dari dosen tersebut sudah diterima sehingga dosen juga dapat memantau sejauh mana laporan yang diajukan tersebut sudah dikerjakan. Dosen dan admin juga dapat melihat grafik yang menunjukkan seberapa sering fasilitas tersebut mengalami kerusakan. Berikut ini merupakan diagram activity keseluruhan dari proses laporan kerusakan.

\section{FlowChart}

.

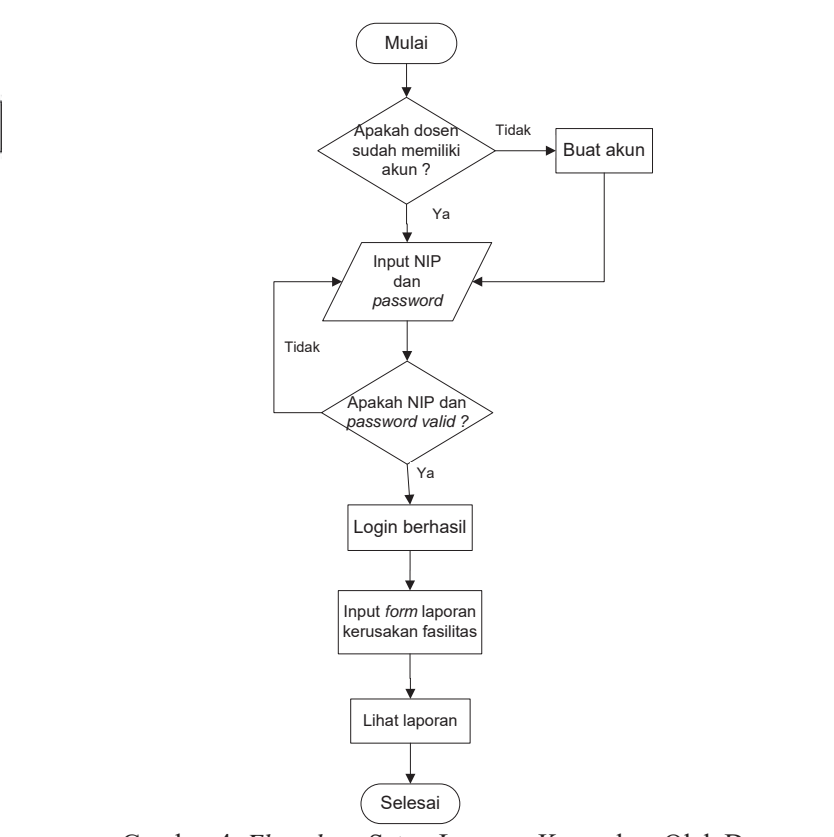

Gambar 4 Flowchart Setup Laporan Kerusakan Oleh Dosen

Gambar 4 merupakan alur dari cara melakukan/pengisian form pada formulir laporan kerusakan fasilitas kelas. Proses dimulai dari login, namun jika dosen yang akan mengajukan laporan belum memiliki akun, maka harus membuat akun terlebih dahulu kemudian melakukan login. Kemudian setelah login akan ditampilkan formulir kerusakan fasilitas kelas yang harus diisi oleh dosen. Setelah selesai mengisi formulir, dosen dapat melihat laporannya sendiri pada bagian laporan. Setelah dosen melakukan pengisian formulir dan melihat laporan yang diajukan, dosen dapat keluar dari sistem dengan melakukan logout.
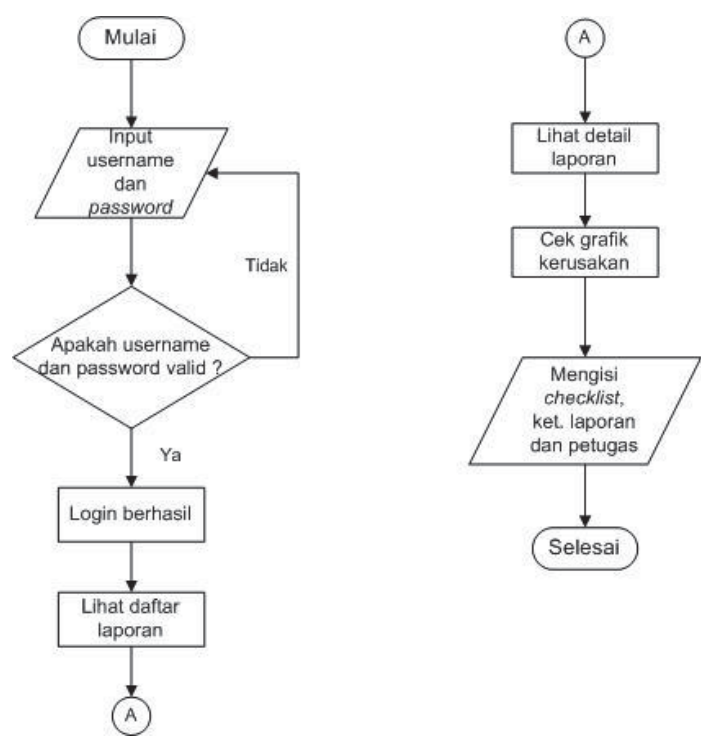

Gambar 5 Flowchart Kelola Laporan Kerusakan Oleh Unit

Gambar 5 merupakan alur dari pengelolaan kerusakan yang akan dilakukan oleh user unit. Pertama dimulai dengan melakukan login terlebih dahulu. Setelah login berhasil halaman awal yang akan ditampilkan adalah daftar laporan dari dosen yang fasilitasnya dikelola oleh unit tersebut. Seletah melihat laporan, maka unit dapat melihat detail laporan dan pada detail laporan tersebut berisi lebih lengkap tentang informasi dari laporan yang diajukan. Pada bagian 
detail laporan ini juga unit akan melakukan checlist apabila sudah menerima laporan, checklist proses apabila laporan sedang dikerjakan, dan juga selesai apabila laporan sudah selesai dikerjakan. Unit dapat melihat grafik kerusakan yang menjelaskan banyaknya total keluhan dari fasilitas yang rusak tersebut. Kemudian apabila unit telah selesai melakukan pengelolaan laporan kerusakan, dapat keluar dari sistem dengan logout.

Gambar 6 adalah alur dari proses untuk melakukan setup kelas dan fasilitas yang akan dilakukan oleh admin. Proses diawali dengan login terlebih dahulu. Kemudian admin beralih kehalaman kelas dan melakukan tambah kelas kemudian data kelas disimpan. Setelah kelas ditambahkan, kemudian admin melakukan tambah fasilitas sesuai dengan kelas yang dipilih. Admin melakukan tambah fasilitas sesuai dengan fasilitas apa saja yang terdapat di kelas tersebut kemudian dilakukan penyimpanan. Berikut ini merupakan flowchart dari proses setup kelas dan fasilitas kelas. Berikut ini merupakan flowchart dari proses melakukan setup kelas dan juga fasilitas yang dilakukan oleh admin.

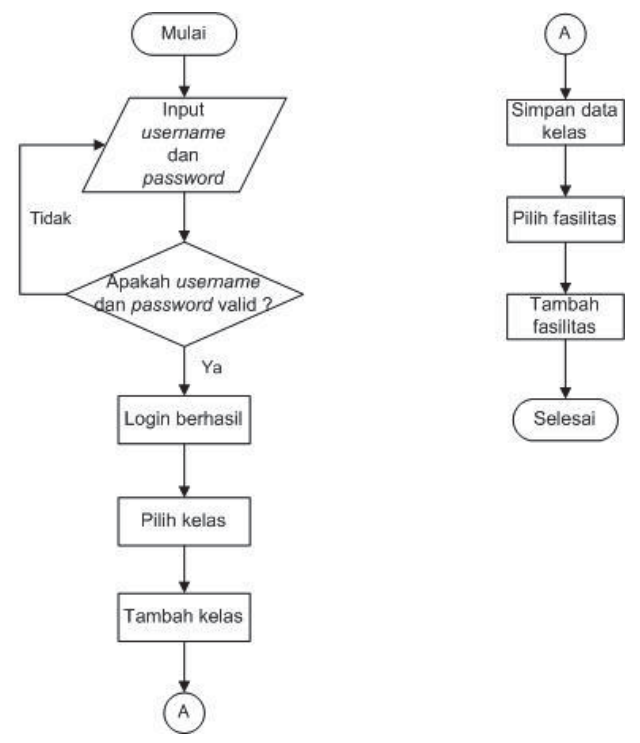

Gambar 6 Flowchart Proses Setup Kelas dan Fasilitas Kelas Oleh Admin

Gambar 7 dibawah ini merupakan alur dari setup fasilitas yang akan dilakukan oleh admin. Setup fasilitas ini berfungsi untuk menambahkan fasilitas dan unit yang bertanggungjawab dalam pengelolaan fasilitas tersebut. Dimulai dengan login terlebih dahulu kemudian admin beralih ke halaman fasilitas. Pada halaman fasilitas admin akan menambahkan data fasilitas dengan mengisi form yang berisi nama fasilitas dan unit yang mengelola kemudian disimpan. Fasilitas ini juga yang akan berguna pada fitur fasilitas kelas. Admin tidak perlu melakukan ketik manual pada saat melakukan input fasilitas kelas. Admin hanya perlu memilih fasilitas yang sudah disediakan yang berasal dari data fasilitas. Berikut ini merupakan flowchart dari proses setup fasilitas yang dilakukan oleh admin.

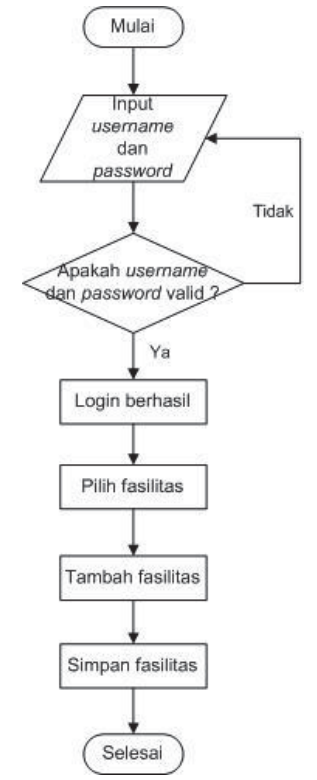

Gambar 7 Flowchart Proses Setup Fasilitas Oleh Admin

\section{Model Data Logika (MDL)}

Model data logika merupakan suatu teknik yang menjelaskan struktur proses bisnis dan aturan-aturan sebagai masukan dalam perancangan database. Teknik yang dapat digunakan pada perancangan basis data yaitu Model Data Logika (MDL). Didalam model data logika menjelaskan struktur informasi bisnis dan aturan-aturan sebagai masukan pada proses perancangan database. MDL terdiri dari 8 tahap antara lain : identifikasi entitas utama, hubungan antar entitas, menentukan kunci primer dan kunci alternatif, menentukan kunci tamu, menentukan kunci aturan bisnis, penambahan atribut bukan kunci, validasi aturan normalisasi, dan menentukan domain. Entitas-entitas yang akan digunakan antara lain: Admin (berfungsi untuk mencatat seluruh data admin), Dosen (mencatat seluruh data dosen), Unit (mencatat seluruh data unit), Kelas (mencatat data kelas), Fasilitas (mencatat data keseluruhan fasilitas), Fasilitas Kelas (mencatat data fasilitas yang terdapat dikelas), Laporan (mencatat data laporan), Fakultas (mencatat data fakultas).

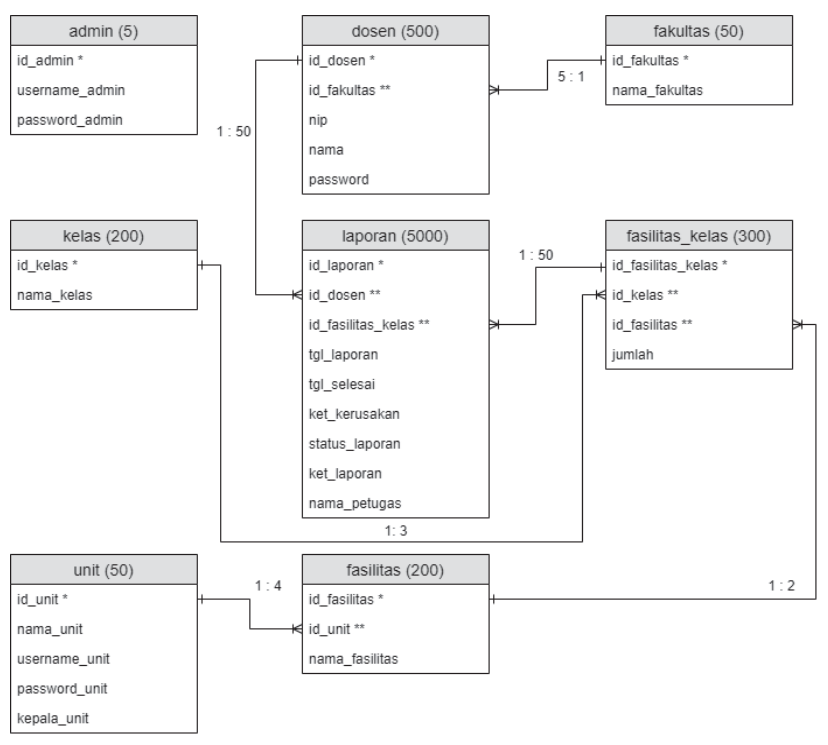

JUTEI Edisi Volume.3 No.2 Oktober 2019 ISSN 2579-3675, e-ISSN 2579-5538 DOI 10.21460/jutei.2019.32.188 
Gambar 8 MDL 6 : Penambahan Atribut Bukan Kunci

\section{IMPLEMENTASI DAN ANALISIS SISTEM}

\section{a. Implementasi Sistem}

Pada bagian tahap implementasi sistem akan berisi tentang tahap penerapan sistem sehingga sistem tersebut akan siap untuk digunakan. Pada tahap ini menjelaskan mengenai proses dalam penerapan sistem serta fungsi-fungsi yang ada didalamnya. Berikut akan ditampilkan fungsifungsi, proses, disertai dengan potongan program untuk menjalanan fungsi tersebut. Sistem ini dibangun dengan menggunakan bahasa pemograman PHP (Hypertext Prepocessor) dan menggunakan basis data MySQL. Sistem Informasi Pelaporan dan Penanganan Kerusakan Fasilitas Kelas dapat diakses setelah terkoneksi dengan database karena semua data yang akan diolah berada dalam database.

\section{b. Tampilan Login}

Pada autentikasi user ini digunakan untuk melakukan pengecekan masukan dari pengguna dengan database. Halaman login merupakan tampilan yang pertama kali muncul ketika sistem dijalankan. Halaman ini berfungsi untuk memeriksa pengguna yang akan masuk kedalam sistem berdasarkan hak akses pengguna. Pengguna pada sistem ini dibagi menjadi tiga yaitu dosen, unit, serta admin. Berikut ini tampilan dari halaman login.

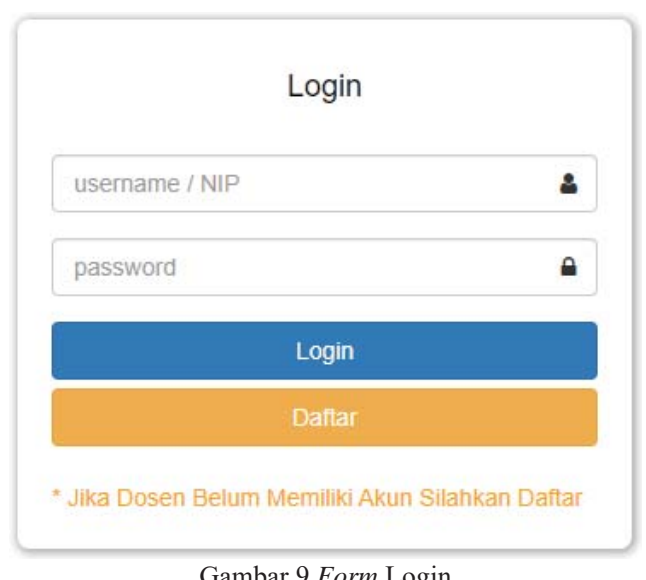

Gambar 9 Form Login

Setelah tampilan login berhasil dibuat, maka tahap selanjutnya yaitu melakukan autentifikasi kode dan password yang di inputkan atau proses pengecekan antara username dan password sudah sesuai dengan database atau belum. Dihalaman ini pengguna harus masuk dengan username dan password sesuai yang dimiliki atau telah dilakukan pendaftaran sebelumnya.

\section{c. Tampilan Halaman Utama}

Pada tampilan sistem dibawah ini digunakan ketika pengguna mengakses web Sistem Informasi Penanganan dan Pengelolaan Kerusakan Fasilitas Kelas. Pada halaman utama terdiri dari 5 bagian yaitu header (nomor 1), menu navigasi (nomor 2), serta bagian isi web (nomor 3). Untuk keseluruhan Pada bagian header berfungsi untuk menampilkan judul dari sistem. Menu navigasi terdiri dari bagian nama user yang sedang aktif dan juga jenis user (dosen/unit/admin) yang dibuat secara center agar posisi berada ditengah dan memiliki jarak kedalam sebesar $15 \mathrm{px}$. Kemudian bagian menu pada navigasi berisi tentang menu- menu yang terdapat pada halaman user ketika login. Pada halaman ini merupakan contoh dari login unit sehingga menunya terdiri dari daftar laporan kerusakan, grafik laporan, serta fitur logout. Menu pada navigasi dibuat secara hover agar dapat memberikan efek ketika kursor diarahkan dan jarak kedalam (padding) sebesar 10px. Selanjutnya pada bagian nomor 3 merupakan isi dari halaman ketika fitur dibuka. Pada tampilan dibawah ini merupakan contoh dari halaman utama login krt yang berisi daftar laporan. Halaman isi akan menyesuaikan dengan fitur yang dibuka. Desain halaman utama ini digunakan untuk semua user yaitu dosen, unit, serta admin. Berikut ini tampilan dari desain halaman utama.

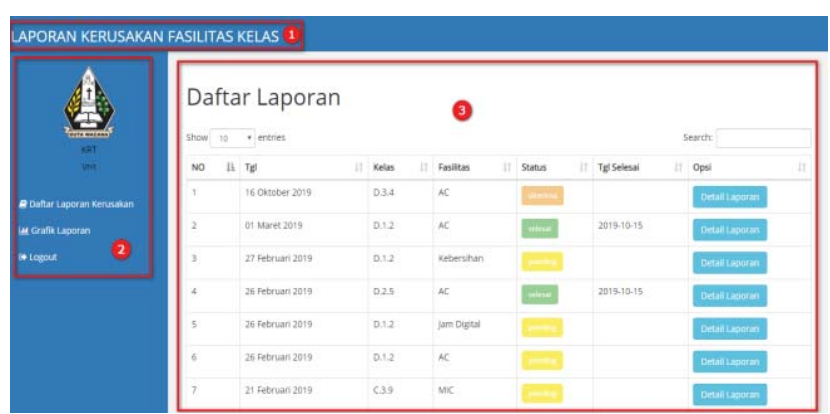

Gambar 10 Tampilan Halaman Utama

\section{d. Tampilan Input Data Ke Database}

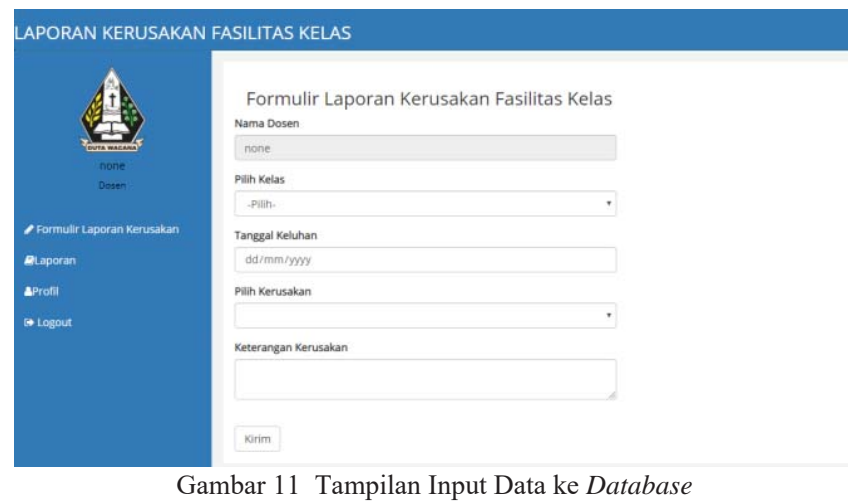

Entri data ke database adalah proses memasukkan data dari pengguna ke database melalui sistem. Pada sistem ini data yang dimasukkan ke dalam database adalah data formulir laporan kerusakan fasilitas kelas, detail laporan, data kelas, data fasilitas kelas, data fasilitas, serta data dosen. Salah satu contoh yang akan dijelaskan adalah data setup formulir laporan kerusakan fasilitas kelas. Berikut ini sebagai contoh untuk menampilkan data pada halaman formulir laporan kerusakan fasilitas kelas.

Pada halaman tersebut, terdapat textbox yang menampilkan nama dosen secara otomatis sesuai dosen yang masuk kedalam sistem dan tidak dapat dilakukan edit karena bersifat readonly. Selain itu juga terdapat textbox yang disediakan untuk melakukan input kelas, tanggal keluhan, pilih kerusakan, serta keterangan kerusakan. Apabila sudah terisi, klik tombol kirim. Kemudian data yang di input akan masuk ke dalam database pada tabel-tabel yang membutuhkan data tersebut. 


\section{e. Tampilan Menampilkan Data Dari Database}

Halaman tampil data dari database merupakan halaman yang dapat menampilkan data yang telah dimasukkan kedalam database. Pada sistem ini halaman-halaman yang menampilkan data dari database antara lain halaman daftar laporan kerusakan fasilitas kelas di semua user, detail laporan, halaman kelas, halaman fasilitas kelas, halaman fasilitas, serta halaman dosen. Berikut ini salah satu contoh halaman untuk menampilkan data dari daftar laporan kerusakan pada login admin.

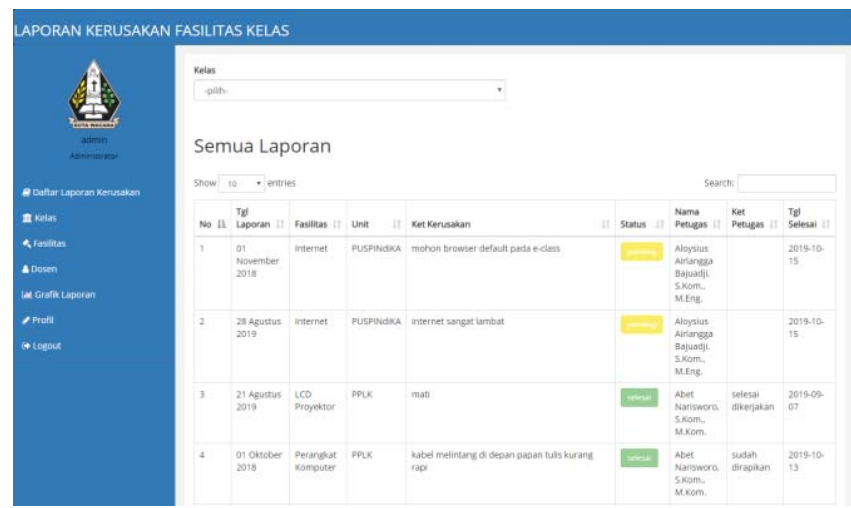

Gambar 12 Tampilan Menampilkan Data Dari Database

\section{f. Tampilan Ubah data}

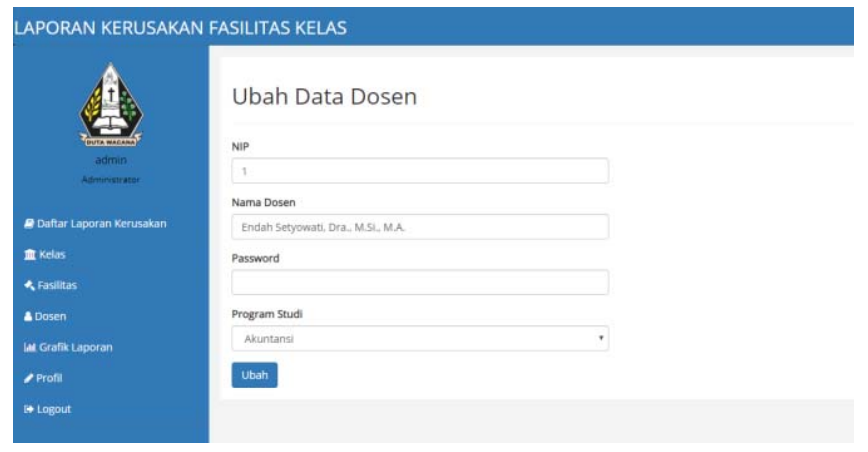

Gambar 13 Halaman Ubah Data

Pada proses melakukan ubah data merupakan halaman yang dapat melakukan pengubahan data yang telah dimasukkan ke dalam database. Pada sistem ini halamanhalaman yang dapat melakukan ubah data dari database antara lain halaman profil dosen, kelas, fasilitas kelas, fasilitas, dosen, profil admin. Berikut ini salah satu contoh dari tampilan ubah data dosen pada user admin.

Pada halaman untuk melakukan ubah data dari database terdapat textbox untuk menampilkan data dosen yang sudah dibuat sebelumnya oleh dosen ataupun admin. Selanjutnya admin dapat melakukan ubah data dosen pada halaman tersebut dengan mengubah data yang terdiri dari NIP dosen, nama dosen, serta memilih program studi. Setelah itu klik ubah untuk melakukan perubahan data. Data yang sudah dirubah tersebut akan tersimpan kembali kedalam database sesuai dengan data yang sudah dilakukan perubahan.

\section{g. Tampilan Hapus data}

Pada proses melakukan hapus data merupakan halaman yang dapat melakukan penghapusan data yang telah dimasukkan ke dalam database. Pada sistem ini halamanhalaman yang dapat melakukan hapus data dari database antara lain halaman kelas, fasilitas kelas, fasilitas, serta dosen pada halaman admin. Berikut ini salah satu contoh dari hapus data halaman fasilitas kelas pada user admin.

Pada halaman untuk melakukan hapus data dari database melalui tampilan fasilitas kelas dilakukan dengan cara klik pada icon hapus sesuai dengan data yang dipulih untuk dilakukan penghapusan, kemudian akan tampil notifikasi dari localhost sebagai sebagai konfirmasi penghapusan data. Ketika konfirmasi hapus data di klik oke, maka data yang dipilih tersebut akan terhapus dari database dan halaman fasilitas kelas.

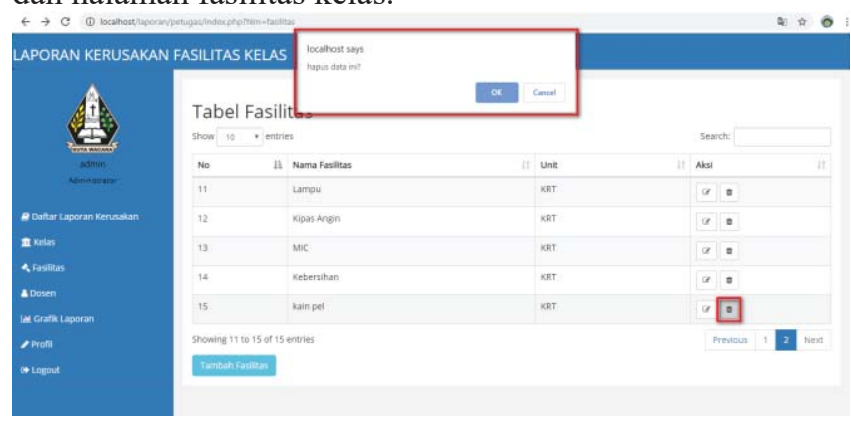

Gambar 14 Tampilan Melakukan Hapus Data

\section{h. Proses Menampilkan Grafik}

Menampilkan grafik merupakan halaman yang memuat grafik agar user lebih mudah melihat statistik fasilitas yang sering mengalami kerusakan.pada sistem ini halamanhalaman yang akan menampilkan grafik yaitu pada halaman grafik laporan pada unit dan juga admin. Sebelum grafik ditampilkan, user terlebih dahulu memilih fasilitas yang akan ditampilkan grafiknya kemudian klik lihat grafik.

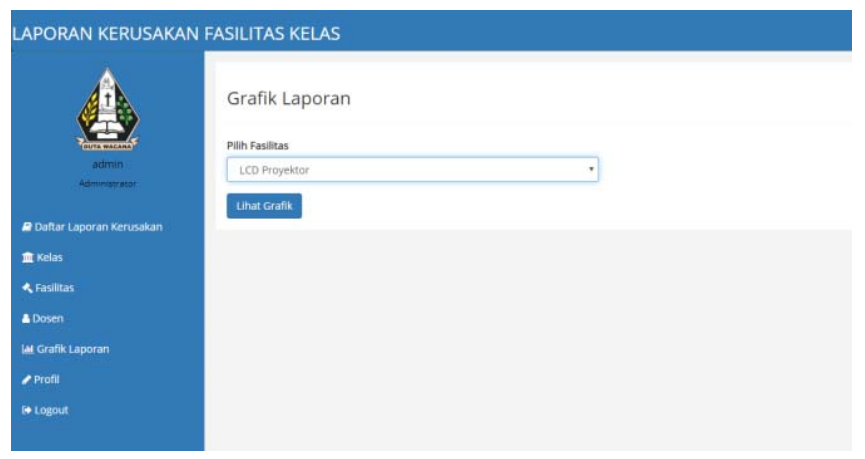

Gambar 15 Halaman Pilih Fasilitas Untuk Grafik

Gambar 15 merupakan tampilan pilih fasilitas berfungsi untuk menampilkan fasilitas yang akan ditampilkan grafik kerusakan dari fasilitas tersebut. Pilih fasilitas ini hanya akan menampilkan daftar fasilitas yang dikelola oleh unit yang melakukan login. Setelah dilakukan klik pada tombol lihat grafik maka akan ditampilkan grafik dari fasilitas yang dipilih seperti contoh berikut ini grafik dari fasilitas AC.

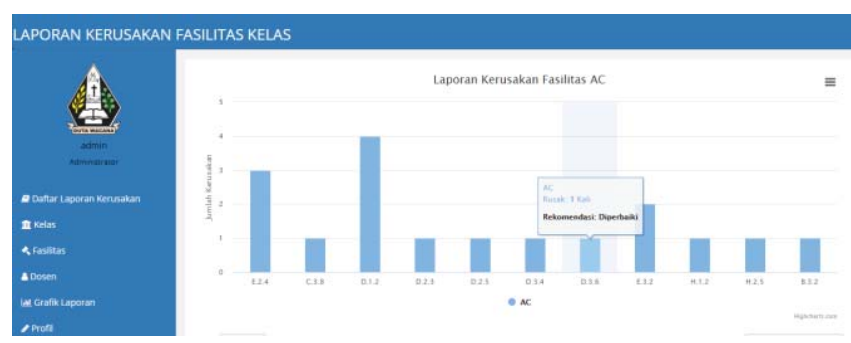

JUTEI Edisi Volume.3 No.2 Oktober 2019 ISSN 2579-3675, e-ISSN 2579-5538 DOI 10.21460/jutei.2019.32.188 
Gambar 16 Tampilan Grafik

Pada gambar diatas menampilkan grafik dari laporan kerusakan. Setelah dilakukan pilih fasilitas, kemudian akan ditampilkan grafik dari fasilitas yang sudah dipilih. Dibagian sumbu $\mathrm{Y}$ yang terdapat pada grafik berfungsi untuk menampilkan jumlah dari kerusakan, sedangkan pada sumbu $\mathrm{X}$ berfungsi untuk menampilkan data kelas dari fasilitasnya yang mengalami kerusakan dengan keterangan fasilitas pada bagian bawah. Selanjutnya ketika kursor diarahkan pada sala satu bar chart, akan ditampilkan keterangan jumlah kerusakan dan rekomendasi kerusakan(diperbaiki/diganti).

\section{i. Tampilan Error Handling Pada Halaman}

Error handling merupakan bagian yang sangat penting karena dapat membantu pengguna sistem ini dalam menjalankannya. Error handling biasanya muncul ketika salah menuliskan data atau ada data yang wajib di input namun belum dilakukan input data seperti contoh diatas, sehingga dengan adanya error handling ini dengan mudah dapat mengetahui kesalahan yang sedang terjadi. Pada gambar diatas sebagai contoh ditampilkan pada halaman formulir laporan kerusakan fasilitas kelas. Berikut ini merupakan salah satu tampilan untuk menampilkan error handling.

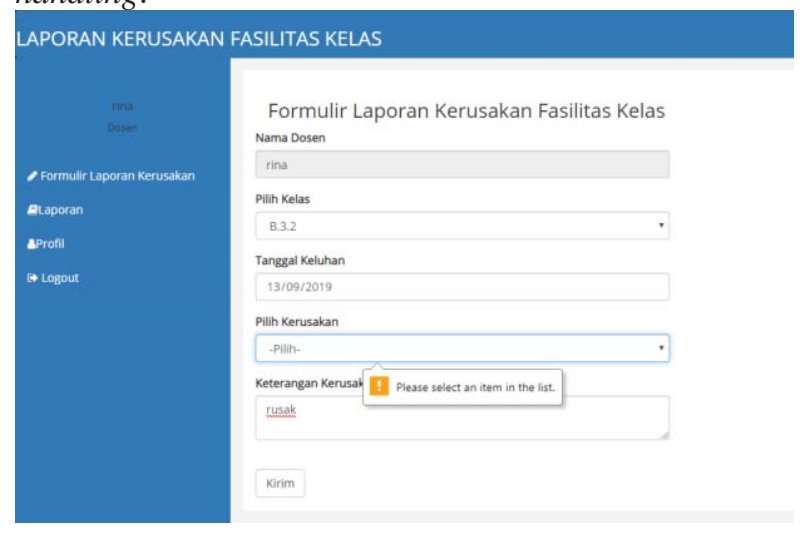

Gambar 17 Tampilan Error Handling

\section{j. Analisis Sistem}

Sistem Informasi Pelaporan dan Penanganan Kerusakan Fasilitas Kelas ini bertujuan untuk mempermudah dosen dalam melaporkan apabila terjadi kerusakan fasilitas kelas atau terdapat fasilitas yang tidak berfungsi ketika akan digunakan saat perkuliahan berlangsung melalui sistem berbasis komputer. Selain itu juga dapat meminimalisir hilangnya data laporan apabila data sudah banyak tersimpan, karena penyimpanan dilakukan pada database.

Setelah data tersimpan, unit dan admin dapat melihat atau dapat melakukan visualisasi fasilitas yang sering mengalami kerusakan dan menjadi keluhan melalui dashboard (grafik) karena berisi informasi tentang fasilitas sudah berapa kali mengalami kerusakan dan juga terdapat rekomendasi kerusakan. Apabila kerusakan baru terjadi satu kali maka rekomendasi yang ditampilkan yaitu fasilitas diperbaiki, namun jika kerusakan sudah terjadi lebih dari satu kali maka rekomendasi yang ditampilkan yaitu fasilitas diganti. Selain itu juga tersedia fasilitas checklist status laporan dari unit agar dosen dan admin juga dapat memantau proses pengerjaan laporan. Status laporan dibedakan berdasarkan 5 warna antara lain : warna kuning (Pending), orange (Diterima), biru (Proses), merah (Diganti), dan hijau (Selesai).

Dalam pembangunan Sistem Informasi Pelaporan dan Penanganan Kerusakan Fasilitas Kelas, masih memiliki beberapa kekurangan karena keterbatasan dalam pembangunan sistem antara lain belum mampu melakukan penghapusan pada daftar laporan kerusakan. Selain itu, Sistem hanya dapat menampilkan rekomendasi kerusakan secara keseluruhan fasilitas, jika fasilitas mengalami 1 kali kerusakan maka rekomendasi yang tampil yaitu diperbaiki. Sedangkan apabila fasilitas mengalami lebih dari 1 kali kerusakan maka rekomendasinya diganti. Kemudian, Sistem belum mampu menampilkan tanggal selesai laporan dikerjakan untuk mengetahui berapa lama laporan dikerjakan, dan juga sistem ini memerlukan koneksi internet pada beberapa fitur yaitu grafik dan fasilitas search pada tampilan untuk dapat diakses.

\section{V.KESIMPULAN DAN SARAN}

Berdasarkan hasil implementasi dan analisis dari sistem yang telah dibangun, maka dapat diambil kesimpulan sebagai berikut :

1. Sistem Informasi Pelaporan dan Penanganan Kerusakan Fasilitas Kelas dapat dibuat dengan program berbasis komputer.

2. Dashboard atau grafik dapat memvisualisasikan fasilitas yang sering menjadi keluhan dan mengalami kerusakan serta memberikan rekomendasi kerusakan.

3. Sistem dapat menyediakan fasilitas checklist status dari Laporan Kerusakan Fasilitas Kelas melalui unit, sehingga dosen dan admin dapat memantau proses pengerjaan laporan.

Keterbatasan kemampuan yang dimiliki oleh pembangun Sistem Informasi Pelaporan dan Penanganan Kerusakan Fasilitas Kelas masih terdapat kelebihan dan kekurangan. Adapun saran untuk pengembangan sistem informasi ini antara lain :

1. Sistem mampu memberikan fasilitas hapus data pada laporan kerusakan agar tidak terjadi penumpukan data apabila penyimpanan sudah banyak.

2. Sistem mampu menampilkan rentang waktu lama pengerjaan laporan.

3. Fitur grafik dan search pada tampilan dapat diakses tanpa memerlukan koneksi internet.

4. Sistem mampu diakses pada mobile berbasis android, windows phone, serta IOS.

\section{DAFTAR PUSTAKA}

[1] N. C. Aridhianto, "Analisis Kondisi Fasilitas Belajar Dan Motivasi Belajar Siswa Kelas Atas," Hubungan Fasilitas Belajar, 2015.

[2] A. M. Y. Putri dan S. A. Muhidin, "Survei tentang standar fasilitas pembelajaran di SMK Pasundan 1 Bandung," Jurnal Pendididkan Manajemen Perkantoran, vol. 3, pp. 240-284, Januari 2018.

[3] S. W. Mursalim, "Analisis Manajemen Pengaduan Sistem Layanan Aspirasi Pengaduan Online Rakyat (Lapor) di Kota Bandung," Jurnal Ilmu Administrasi (JIA), vol. 15, pp. 1-17, Juni 2018.

[4] H. P. Wibowo dan H. Sismoro, "Analisis Dan Perancangan Sistem Informasi Penjualan Barang,” Jurnal Dasi, vol. 13, 3 September 2012 . 
[5] R. Asmara, "Sistem Informasi Pengolahan Data Penanggulangan Bencana Pada Kantor Badan Penanggulangan Bencana Daerah (Bpbd) Kabupaten Padang Pariaman,” Jurnal J-Click, vol. 3, 2 Desember 2016.

[6] E. Iswandi, "Sistem Penunjang Keputusan Untuk Menentukan Penerimaan Dana Santunan Sosial Anak Nagari dan Penyalurannya Bagi Mahasiswa dan Pelajar Kurang Mampu di Kenagarian BarungBarung Balantai Timur," Jurnal Teknoif, vol. 3, p. 2, Oktober 2015.

[7] C. Tristianto, "Penggunaan Metode Waterfall Untuk Pengembangan Sistem Monitoring dan Evaluasi Pembangunan Pedesaat," Jurnal Teknologi Informasi ESIT, vol. 12, p. 1, April 2018.

[8] A. Febrina dan Ardoni, "Perancangan Database Berbasis Web Sebagai Media Temu Kembali Arsip di Kantor Pusat Komputer Universitas Negeri Padang," Jurnal Ilmu Informasi Perpustakaan dan Kearsipan, vol. 2, p. 1, September 2013.

[9] H. Kuswanto, "Analisis Prinsip Layout and Composition pada Web Design Perusahaan PT. Bank Rakyat Indonesia, Tbk dan PT. FIF Group berdasarkan Buku "The Principle of Beautifull Website Design (2nd Edition) By Jason Beaird", "' Jurnal Electronics, Informatics, and Vocational Education (ELINVO), vol. 2, Mei 2017.

[10] A. H. Suyanto, Step By Step Web Design : Theory and Practices, Yogyakarta: Andi Offset, 2009.

[11] H. Kurniawan, "Pengembangan Penerapan Sistem Parkir," Jurnal Informatika, vol. 11, p. 2, Desember 2011

[12] Ilhamsyah dan S. Rahmayudha, "Perancangan Model Dashboard Untuk Monitoring Evaluasi Mahasiswa," Jurnal Informatika : Jurnal Pengembangan IT (JPIT), vol. 2, p. 1, Januari 2017.

[13] D. Bachtiar dan Atikah, "Sistem Informasi Dashboard Kependudukan di Kelurahan Manis Jaya Kota Tangerang," Jurnal Sisfotek Global, vol. 5, p. 1, Maret 2015. 